\title{
FREE SPEECH IN THE INDIAN CONSTITUTION; BACKGROUND AND PROSPECT
}

\author{
PRADYUMNA K. TRIPATHI广
}

SINCE 1945, many new nations have been constructed by revolution, partition or voluntary grants of sovereignty. Written constitutions, commonly prepared in greater or less haste, have in one country after another defined the scope of the new government's powers and have declared the rights of citizens who had but recently been subjects with little voice in their own affairs. Some observers have viewed skeptically the repeated constitutional enunciation of "democratic freedoms." The skeptics have doubted that concepts deep-rooted in the experiences of Britain or the United States, for example, could effectively be transported to lands where different traditions and values had long prevailed. To some extent, the very existence of a free world hinges upon the validity of that skepticism. This Article undertakes to show that in at least one of the new nations-indeed, in one of the most important of them-the soil has been well prepared to nourish the basic freedom, the freedom to express differences of opinion. The Constitution of India embodies a detailed scheme of "ordered liberty," with a full-fledged parliamentary democracy and a system of judicial control to preserve individual rights even against a popular majority. But if the constitution were merely a form of words, unsupported by understanding and true sentiment, it would provide a facade behind which dangers to freedom might grow large and undetected. An understanding of Indian institutions is necessary to an appraisal of liberty's chance to survive, for without their support, the constitution would be an embodiment of empty platitudes.

\section{The Guarantees of the Indian Constitution}

Upon realization of the dream of independence in 1947,1 India prepared and adopted a constitution, which became effective on January 26,1950 . Its objects, as declared in the preamble, are:

"to secure to all its citizens:

"JUSTICE, social, economic and political;

"LIBERTY of thought, expression, belief, faith and worship;

"EQUALITY of status and opportunity; and to promote among them all "FRATERNITY assuring the dignity of the individual and the unity of the Nation."

$\dagger$ Faculty of Law, University of Delhi. The author acknowledges the kind assistance of David J. Bardin, member of the New York Bar. The present Article is based upon a dissertation prepared by the author in partial satisfaction of the requirements for the S.J.D. degree at Columbia University Law School.

1. By the Indian Independence Act, 1947, $10 \& 11 \mathrm{Gzo} .6$, c. 30. 
The constitution provides for a democratic and federal scheme of government. Cabinets, responsible to the legislature after the English pattern, rule both the union and the states; and a system of independent checks is established. ${ }^{2}$

The constitution guarantees, as "Fundamental Rights," the civil liberties of the individual against encroachment by any agency, including the legislature, ${ }^{3}$ and commits their defense to an independent judiciary. ${ }^{4}$ Freedom of speech and its complementary rights of public meeting and free association are among the Fundamental Rights. ${ }^{\overline{7}}$ In its present form, ${ }^{6}$ the speech guarantee reads:

"19. (1) All citizens shall have the right-

" $(a)$ to freedom of speech and expression;

". . .

"( $(\dot{2})$ Nothing in sub-clause (a) of clause (1) shall effect the operation of any existing law or prevent the State from making any law, in so far as such law imposes reasonable restrictions on the exercise of the right conferred by the said sub-clause in the interests of the security of the State, friendly relations with foreign States, public order, decency or morality, or in relation to contempt of Court, defamation or incitement to an offence." 7

The courts must arbitrate between the individual and restrictive government, and, in doing so, must pass upon the reasonableness of restrictions in the enumerated cases.

The free speech provision, in the setting of the other Fundamental Rights, is designed to afford the people of India the kind and measure of liberty available to the individual in the United Kingdom or in the United States. The Indian Constitution does, indeed, depart from the American and British systems in major points of form, technique and method-even as these two differ from each other. But the deviations from British and American patterns do not derogate from the underlying principles of individual liberty; these principles permeate the form and practice of the Indian scheme-as they do in any true democracy.

2. Articles 74, 75, 163 and 164 provide for cabinet government for both union and states. The constitution secures free, impartial and regular elections conducted by an independent "Election Tribunal." See INDIA Const. arts. 324-26. It contemplates an independent Auditing Authority, id. art. 148, and independent public service commissions for the union and each state, $i d$. art. 315 , to ensure equal opportunity for administrative service.

3. The guarantee is against encroachment by union as well as by state government. Id. art. 12.

4. The supreme court, $i d$. art. 32 , as well as the high courts, $i d$. art. 226, is authorized to issue writs for enforcement of such rights. A judge of the supreme court holds office until the age of sixty-five; and a judge of a high court until sixty. Each has the usual protection against removal from office or impairment of privileges and allowances. Id. arts. $124,125,217,218$.

5. Id. art. 19.

6. Clause 2 of article 19 was amended in 1951. Previously, the exceptions under the free speech clause were narrower than those applicable to the other rights.

7. "State" includes the union government. See id. art. 12. 


\section{The Democratic Idea and the India of Today}

However exalted the principles of the constitution, some degree of anxiety exists and has been expressed as to whether they can survive in the India of today. Grave difficulties, one commentator has suggested, "may soon emerge due to the fact that a system of Parliamentary democracy has been imposed on a system of administration appropriate to a colonial regime in a dependent territory." Another highly regarded student of the problem of the new nations of southeast Asia has observed:

"Although the analogy is in many respects unfair and should certainly not be pressed too far, it may be suggested that just as the colonial governments were imposed on the people from above and outside, so the new Western-style constitutions have been the work of small groups whose intellectual and, in a sense, political links are with the West rather than with the mass of their own people."

Doubts of this sort deserve careful evaluation, for they are not the expressions of ill-willed or uninformed men. In India, concern over the survival of democratic constitutional precepts rises from four factors: Hinduism; the illiteracy of the masses; the poverty and the low standard of living of the common man; the lack of democratic and libertarian traditions among the people. Of these, the last is believed to pose the most serious challenge.

\section{Hinduism}

The charge has been made that the Hindu religion, with its fatalistic teachings, promotes a tendency to accept passively whatever happens and thus dulls "the sharp edge of protest for the individual, convincing him that his misery was necessary and even holy." 10 This asserted tendency led Norman Cousins to ask Prime Minister Nehru: "Wasn't it difficult to interest an individual in democratic reform and in the right of protest if he felt he was paying for the sins of a previous incarnation?" To this, Mr. Nehru replied that "there was nothing inconsistent between Indian philosophy or religion and democracy."11 Of course, Hinduism, like other ancient religions, developed without any reference to the more recent political ideas of democracy and freedom. And, in common with any other religion, Hinduism presents facets that can reasonably be drawn upon to bless conflicting sacial or political claims. Thus, the undemocratic social stratification implied in the caste system might be cited on the one hand, and, on the other, the infinite diversity of religious beliefs, ideologies and modes of worship that are comfortably accommodated and implied within Hinduism. ${ }^{12}$ If Hinduism be viewed as a whole, the breadth of its tolerance

8. Bailey, Parlianentary Government in South Asia, Institute of Pacific Relations, New York, 1952, p. 26.

9. Emerson, Representative Government in Southeast Asia 11 (1955).

10. Nehru \& Cousins, Talks With Nemru 10 (1951).

11. Id. at 10-11.

12. For instance, Hinduism holds within its fold the atheism of the Jains, the monotheism of the bulk of the Hindus and an infinite variety of polytheistic beliefs. The 
and the dynamism of the theory of "Karma" tip the scales in favor of individualistic values. ${ }^{13}$ Modern political leadership has fully exploited this religious tradition to convince the Indian masses of the values of democracy and freedom.

\section{Illiteracy}

Modern ideas of freedom have been passed on to the south and southeast Asian peoples through contact with those European nations that took the lead in the material and cultural advancement of the last two centuries. Illiteracy is no doubt a great handicap to the assimilation of these new and foreign principles. Nonetheless, the handicap is susceptible of exaggeration. While a high incidence of literacy in the more advanced countries has long ceased to be an exciting achievement, present-day standards of literacy should not lead us to forget that some of the greatest cultural revolutions, in the East as well as the West, occurred when the bulk of the people involved were still illiterate. In India, for instance, the entire subcontinent was converted to Buddhism in the course of a few centuries; and then, within the short life span of a remarkable man who died at the age of thirty-two, the country was cleared of Buddhist influence and reclaimed to the Brahmanic faith. ${ }^{14}$ Similarly, in the West itself, literacy was not widespread at the time of the British revolutions of the seventeenth century, nor was "book learning" a characteristic of the American farmers and artisans who in the late eighteenth century provided the base upon which a new democracy was built.

Moreover, since the family bond remains strong in India, the separation between the educated and illiterate is perhaps less rigid than in the West. A large proportion of families that are divided by partial migrations to the

Jains, the Arya Samajists and the Brahmo Samajists do not recognize caste. Examples of this kind could be multiplied. For a balanced and authoritative treatment, see RADHAKRISHNAN, The Hindu View of LifE lecture II (1927).

13. "Karma" literally means "action." The theory of "Karma" propounded in The Bhagazad-Gita (Third Discourse) is based on the axiom of inevitability of action and on the duty of engaging in "right action" and "unattached action." Thus: "Man winneth not freedom from action by abstaining from activity, nor by mere renunciation of activity doth he rise to perfection." The Bhagavad-Gita (ThIRD Discourse) verse 4 (Besant transl. 1923). "Nor can anyone, even for an instant, remain really actionless; for helplessly is everyone driven to action by the qualities born of nature." Id. verse 5 . "Perform thou right action, for action is superior to inaction, and inactive, even the maintenance of thy body would not be possible." Id. verse 8. "There is nothing in the three worlds, $\mathrm{O}$ Partha, that should be done by Me, nor anything unattained that might be attained; yet I mingle in action." Id. verse 22 . "For if I mingled not ever in action, unwearied, men all around would follow My path, $\mathrm{O}$ son of Pritha." Id. verse 23. The divine directive is: "Therefore, without attachment, constantly perform action which is duty, for, by performing action without attachment, man verily reacheth the Supreme." Id. verse 19.

There is no doctrine of "Karma" known to Hinduism other than that embodied in the Bhagaz'ad-Gita, and no Hindu scripture of higher authority exists.

14. He lived towards the end of the eighth century A.D. and is known as Sankar, Sankar-Acharya or Adi-Sankar-Acharya. 
cities continue to consider themselves united, retain close economic and emotional ties and even exchange members between residences. Thus, cultural influences flow quickly, and with a stamp of respectability, from the urban to the rural section.

Furthermore, illiteracy is a condition that can be overcome by purposeful endeavor. Whatever might have been the fervor for freedom with the colonized people of Asia, they could not have achieved a high literacy rate without considerable government co-operation-co-operation that, needless to say, was not freely given. Once Indian independence was won, the advance toward universal education became very rapid. In 1947, for example, only thirty per cent of Indian children in the six-to-eleven age group were school-going, but in less than a decade the percentage nearly doubled.15 Now, under its constitution, India is committed to making education compulsory and free for all children below fourteen, by the year 1960 .

These considerations do not minimize the significance of literacy to democratic institutions. India certainly recognizes it. But, under the circumstances confronting India, to have held dogmatically that literacy was indispensable to such institutions would have been to accept defeat unnecessarily.

\section{Poverty}

The problem of poverty can be overcome only by planned and sustained exertion over a comparatively long period. India is making a mighty effort, the principal effects of which will be discernible only after two decades, when the great irrigation and hydroelectric projects begin to yield their full capacity and the steel mills and other capital goods factories enter large-scale production.

Meanwhile, programs productive of more immediate results-and of rural experience with self-government-are progressing. Land reform, "the single most urgently needed reform in most Asian countries,"16 comes first. In state after state, the peasant is enjoying the direct ownership of land for the first time. The Community Development Projects are bold steps toward bringing economic, educational and hygienic improyements to the mass of India's villages. And, in their execution, the initiative mainly rests with, and the planning is done by, the peasants and the villagers themselves. ${ }^{17}$ The peasant-villager, seemingly the greatest beneficiary of independence thus far, is also experiencing his first taste of self-government. More or less uniform acts passed by the states have vested the village Panchayat-a body of five persons, directly

15. The proportion of school-going children in the age group 6-11 rose from $30 \%$ in 1947 to $40 \%$ by 1951 , and to nearly $50 \%$ for $1955-56$. The total number of students enrolled in the educational institutions in 1953-54 was 29,556,000, of whom 603,000 were enrolled in institutions of higher learning. For further details, see Ministry of INFormaTTON \& BroadCasting, India, 1956, c. XXII, a reference annual published by the Ministry of Information and Broadcasting, Government of India, the source for these figures.

16. Bowles, Amibassanor's Report 175 (1954).

17. Government of India, Planning Commission, Second Five Year Plan c. XI (1956) ; see Bowles, Ambassador's Report 195-214 (1954). 
elected, usually by a simple show of hands-with a modicum of local administrative and even judicial powers. ${ }^{18}$

Thus, while poverty has yet to be banished, the mass of India's people has a stake in the present constitution. Of this, the peasant is fully aware. ${ }^{19}$ Under these circumstances, the peasant-villager of India would not be likely to show enthusiasm for any "alternative method of government." His active assistance or approval, in case of any violent disturbance at the top, is most improbable. On the contrary, he would have strong reasons to oppose any drastic undermining of the democratic and free institutions which have recently given him a heady taste of power. Yet how intensely he will be roused in the defense of these institutions as such, apart from real or supposed prospects of economic uplift, how far his resistance to any attempts to subvert democracy will be organized, intelligent and effective, and what chances exist that adequate leadership will come forward to utilize his spirit, are questions that remain unsolved. Their answer will be found, ultimately, in the extent to which faith in free institutions has penetrated to the grass roots of Indian life. The question of tradition, possibly the Achilles' heel of Asia, thus becomes crucial.

\section{Lack of Democratic Tradition}

To be sure, illiteracy and poverty cast doubt upon the viability of democratic government in Asia generally; but an even more serious challenge lies in the abruptness of democracy's planting on the Asian soil. In the West, as Professor Rupert Emerson has remarked, "the transition from autocracy to democracy was a slow and gradual process. . . . The piecemeal enfranchisement of the segments of the population in a rough way kept pace with the evolution of a new economic and social life and with the spread of mass education and

18. Article 40 of the Constitution of India provides: "The State shall take steps to organise village panchayats and endow them with such powers and authority as may be necessary to enable them to function as units of self-government."

The system obtaining in Uttar Pradesh, which may be taken as more or less duplicated in the other states, is described in INDIA, 1956, op. cit. supra note 15, at 74: "The judicial wing of the panchayat organization is called the Panchayat Adalat. The system as it exists in Uttar Pradesh, requires the Gaon Sabha, which consists of the entire population of a village, to elect five trustworthy persons to act on a judicial panel of 25 to 30 persons in a unit of five or six contiguous villages. Every petty case, civil or criminal, arising in the unit is to be referred, in accordance with prescribed rules, to a tribunal of five nominated out of this panel-one or two from the village where the parties reside, and the rest from the neighboring villages. This tribunal makes enquires locally, and decides the cases on the spot. No appeal is normally allowed against its decision. If gross miscarriage of justice is proved to the satisfaction of a civil judge or a magistrate, he may direct a retrial before another tribunal." See also Report of the Congress Village Panchayat Conmittee (1954).

19. He has shown this awareness unfailingly in the elections when "in every state, how the parties lined up when the counting was over, bore a distinct relationship to local conditions," and the universal criteria of voters' choice have been "good government" and raising the standard of living. Trunburl, As I SeE India 169, 174 (1956). 
literacy."20 In Asia, by contrast, "the modern world has come with a rush and there has been no time for the kind of slow adaptation to new circumstances which was generally characteristic of the West."21

This caution about the future of free institutions in Asia is not groundless. It is largely corroborated by the checkered career of democracy in certain parts of the continent, even during the very brief experience since the second World War. Yet, in this respect, every one of the newly freed Asian nations has its own peculiar make-up. Generalizations, though possible, must be largely qualified in the light of the individuality of each of the various peoples. In India, the principles of liberty rest upon a firmer foundation than the ten years of independence, standing alone, might lead one to expect. An analysis of the main source of the inspiration that has to a marked degree taken the place of an ancient tradition is necessary to an understanding of India's democratic prospects.

\section{The Influence of GandhI}

India does not yet stand entirely clear of the shadow of anxiety about the future of Asian governmental institutions. ${ }^{22}$ The new nation possesses no centuries-old background of individual liberty. Its indigenous governments were not democratic in character, nor did English institutions grow in Indian soil for so long a time that they acquired the acceptance that comes from custom and lengthy acquaintance. Contrary to widespread belief, the British had complete supremacy over India for no more than ninety years; and, for Indians, the first few decades of this period were occupied more by resentment and chagrin than by any attempt to understand with sympathy the new values evolved and proffered by the western way of life.

But, as so often happened in earlier epochs, India's cultural vitality upon exposure to fresh currents compensated to some degree for the brevity of her experience with western institutions. She approached the ideas of democracy and freedom with her own cultural equipment and examined them in the light of her experience. Instead of superficially acquiescing in foreign modes and dogmas, she assimilated and came to possess them as a result of the Gandhian forgoing of links with the familiar values of her past. The Gandhian movement gave leadership to the struggle for independence; it was not a rejection of western ideals, but a translation of them into specifically Indian terms. It grew not as an early and angry protest against foreign domination, but as an expression of matured attitudes, not in fact inconsistent with some of the philosophic conceptions of the western world.

Gandhi first came into prominence at the turn of the century as a vindicator of Indian rights in the Union of South Africa. There, he enunciated his principles of Truth and Non-violence as the means of political struggle and con-

20. EMERSon, op. cit. supra note 9, at 153-54.

21. Id. at 154.

22. In Mr. Trumbull's opinion, "an army coup is not out of the question" in India. Trumbull, As I See India 192 (1956). 
ceived the technique of civil disobedience to force governmental decisions. ${ }^{23}$ By 1920, he had returned to his homeland to become the helmsman of India's struggle for independence. From that time onward, he completely dominated Indian thought and life, not only in politics but in practically all the important phases of the country's cultural existence, including, of course, religion and social reform. The young people who were in their twenties when Gandhi's influence became dominant are now men and women in their sixties, and thus, in a country with a comparatively low life expectancy, constitute the most aged element of the population. Short as is a single human generation in a nation's life, virtually every Indian who is alive today has grown under the influence of the Gandhian movement. Gandhi's teachings of democracy and freedom and India's absorption of his ideas are, accordingly, most significant.

\section{Free Expression in Gandhi's Principles and Program}

The Gandhian movement's scrupulous insistence on Non-violence made it essentially and exclusively one of propaganda. Gandhi's avowed purpose was to secure the country's independence from foreign rule; but he uncompromisingly wedded himself and his followers to nonviolent means for the achievement of that purpose. The inevitable corollary was that speech and writing became the primary tools of political action. Gandhi insisted that the principles of Non-violence extended even to words and thought. Nor could any secrecy exist in any aspect of the movement, since Truth, in a very rigorous and robust form, was another value insisted upon by Gandhi, equally and inseparably with Non-violence. ${ }^{24}$ These conceptions necessarily led to insistence upon the right to dissent:

"In spite, however, of such [single-minded] devotion [to Truth], what may appear as truth to one person will often appear as untruth to another person. But that need not worry the seeker. Where there is honest effort, it will be realized that what appear to be different truths, are like apparently different countless leaves of the same tree. Does not God himself appear to different individuals in different aspects? Still we know that $\mathrm{He}$ is one. But Truth is the right designation of God. Hence there is nothing wrong in every one following Truth according to one's lights. Indeed it is one's duty to do so."25

The usual and recurring points of conflict between a revolutionary movement of this nature and the government against which it was launched were, as could be expected, oppressive press laws, laws prohibiting meetings and pro-

23. Mr. Gandhi first went to South Africa as a privately engaged lawyer in 1893. He led the struggle of the Indian settlers against racial discrimination in South Africa for nearly twenty years. He was first imprisoned in 1902 . He returned to India in 1915 and soon became interested in the national struggle under the auspices of the National Congress.

24. For a doctrinal treatment of Non-violence, and the incompatibility of secrecy with truthful Non-violence, see Diwaker, Satyagraha: The Power of Truth chapters IV, $V(1948)$.

25. Selected Writings of Mahatara Gandhi 47 (Duncan ed. 1951). 
cessions and laws against conspiracy and sedition. Individually and in the aggregate, these laws sought to block patriotic associations and the expression of any opinion likely to create a "bad feeling" toward the government then in power. ${ }^{26}$ Thus, although the Gandhian movement as a whole was a war against the foreign and autocratic government, the successive battles that dramatized the struggle and that captured instant public attention were necessarily fought on the issues of free speech, free press, free association and freedom of public meeting. The condemnation was simultaneously of the foreign government and of its unfailing hostility to the democratic processes; the two aspects were inseparable and even indistinguishable. And the Congress campaign waged under Gandhi's leadership did not merely leave the issue of free speech to the imagination of the people. Its primacy was stressed. Opposition to Britain was always present, but it was, one might say, the negative aspect of the campaign. The positive aspect lay in the active and sustained support of civil liberties.

From the earliest period of Gandhi's leadership, almost every skirmish between the National Congress and the alien government, on whatever ground originally commenced, emitted its first sparks on issues of free expression which, at some stage or other, came to be directly involved. An illustration is the very first occasion when Gandhi appeared on the horizon of Indian politics. The immediate issues were the slaying by British gunfire of some hundreds of political demonstrators in the Punjab, and the failure of the British to insist, in the treaties after the first World War, upon suitable measures for the preservation of Muslim holy places in the old Ottoman Empire. This failure-known in India as the Khilafat-had aroused keen feelings, not only because of the obvious religious aspects of the matter but also because the British government was widely believed to have disregarded solemn undertakings, given in wartime to gain then-needed support. The National Congress demanded that the Punjab massacre be investigated and that the guilty officials be punished. It also pressed for assurances that the British government would stand by its promise to the Indian Muslims. To these demands-redress of the Punjab and the Khilafat wrongs, as they came to be called-the annual session of the National Congress at Nagpur in December 1920 added another: the grant of Swarajya-meaning literally "self-government"-to India. Upon adamant rejection of all the demands, the Congress adopted a Non-Cooperation Resolution that called upon all Indians to cease co-operation with the government. Students were urged to withdraw from government-supported educational institutions. Civil servants were asked to resign their posts. Every Indian was encouraged to decline all titles, honors or privileges the government might seek to extend. The government countered at once by outlawing the National Congress, the Khilafat committees and other nonco-operation volunteer organiza-

26. The expression "disaffection" in the statutory definition of the offense of sedition, Indran Penal Code \$ 124-A (Lal 1929), was interpreted by the Courts and by the Judicial Committee of the Privy Council to mean "absence of afrection" or "bad fueling." King-Emperor v. Sadashiv Narayan Bhalerao, 74 Indian App. L.R. 89 (1947). 
tions. The banning of avowedly nonviolent organizations was received as a direct challenge to the nation's right to express itself. The Congress promptly retorted by calling upon all patriots openly to join the outlawed organizations, to offer themselves for arrest "quietly and without demonstration," to hold committee meetings and to organize peaceable public meetings in defiance of the laws. Thus, in the end, the direct points of the conflict came to be the issues of free speech, public meeting and free association.

The significance of these matters was articulated in the columns of Young India, Gandhi's weekly:

"Swaraj, the Khilafat, the Punjab occupy a subordinate place to the issue sprung upon the country by the Government. We must first make good the right of free speech and free association before we can make any further progress towards our goal. . . .

"The safest and quickest way to defend these rights is to ignore the restrictions.... No cost is too great for purchasing these fundamental rights. And on this there can be no compromise, no parleying, no conference." 27

"The restoration of free speech, free association and free Press is almost the whole Swaraj. I would therefore respectfully urge the conference that is meeting on Saturday next at the instance of Pandit Malaviyaji and other distinguished sons of India to concentrate upon the removal of these obstacles. ... Let us take care of these precious pennies and then the pound will take care of itself."28

The pattern of this early nonco-operation struggle was repeated time after time. Insistent demands were met by repression; repression engendered new struggles for the freedom to make demands. When hard pressed, the government invariably sought to escape embarrassment and unpopularity by swooping down upon the nationalist press, nationalist associations and nationalist expression of opinion. Then the National Congress countered by declaring every other issue "subordinate" to the "issue sprung upon the country by the Government." The masses who looked to the Congress for leadership were advised that "the safest and the quickest way to defend these rights is to ignore the restriction"-and each time this advice met with a wider, more intelligent and more disciplined response from the nation. This simple counsel, to "ignore the restriction," was the complex and much discussed Civil Disobedience.

\section{Gandhian Emphasis Upon the Dignity of the Individual}

Another phase of the Gandhian movement which stressed liberty was the emphasis placed on the individual. The Hindu faith, which Gandhi devotedly professed and to whose teachings he repeatedly referred, regards the individual soul as an end in itself. Hinduism, in one sense, is pre-eminently an individualistic creed; it considers the very purpose and goal of life to be the advancement of the soul, which is invested with the potentiality of attaining

27. Gandhi, Young India 1919-1922, 942-43 (1923).

2S. Id. at 947. 
the supreme condition of Godliness. ${ }^{29}$ To Gandhi, the struggle for India's independence was possibly a part of his personal endeavor toward the purification and advancement of soul. He found himself in politics perhaps only because the spiritual law brought him there. ${ }^{30}$ In any event, his faith in the individual was boundless. "It is possible," he would untiringly assert, "for a single individual to defy the whole might of an unjust empire to save his honour, his religion, his soul and lay the foundation for that empire's fall or its regeneration." 31 In his testimony before the Hunter Committee, Gandhi was asked by Sir Chimanlal Setalvad: "I take it that the strength of the propaganda must depend on the number of its followers." "No," answered Gandhi, "in Satyagraha [literally, 'holding on to Truth'] success is possible even if there is only one Satyagrahi of the proper stamp."32

Love, suffering and courage were the constant keynotes of Gandhi's political preaching. The suffering that his doctrine of Non-violence involved and that runs through the entire Hindu teaching and way of life, is not, as Norman Cousins feared, the suffering of inaction, indifference or passive resignation. It is the suffering of Christ, the suffering involved in the search for Truth or God, suffering as the inevitable price of insistence on right action:

"Non-violence in its dynamic condition means conscious suffering. It does not mean meek submission to the will of the evil doer, but it means the pitting of one's whole soul against the tyrant."33

\section{Gandhi's Synthesis of Western and Indian Values}

The devices Gandhi used to communicate the values of democracy and freedom to the Indian population must not go unnoted. Whether he chose the devices with deliberate forethought, or whether they seemed natural to his religious mind, influenced deeply by the loftiest cultural values of the West,

29. A typical verse of the Gita is illustrative: "He who is happy within, who rejoiceth within, who is illuminated within, that Yogi, becoming the Eternal, goeth to the Peace of the Eternal." The Bhagavad-Gita (Fiftr Discourse) verse 24 (Besant transl. 1923). The entire teaching of the Gita is about the way one individual can reach the perfection of eternal life.

30. "[A] man who aspires after that [Truth] cannot afford to keep out of any field of life... those who say that religion has nothing to do with politics do not know what religion means." GandhI, The Story of My Experinients With Truth 615 (1948). See also Selected Writings of Mahatala Gandhi 59 (Duncan ed. 1951).

31. Id. at 55 .

32. GaNDHI, Young India 1919-1922, 36 (1923). Much later, in 1940, when the Indian National Congress wanted, without damaging the material strength of the Allies, to express national opposition to British intentions to continue to hold India in bondage, Gandhi actually practiced the extreme implications of his faith in the dignity and worth of the individual. He launched against the British government in India what he called individual Satyagraha: one man at a time, from all India, would offer Civil Disobedience and thus court imprisonment. The honor of being the first of these Satyagrahis was given to Vinoba Bhave, the great, but until then obscure, disciple who organized and is engaged in the "Bhoodan"-gift of land for the landless-campaign in free India.

33. Selected Writings of Mahatma Gandiri 49 (Duncan ed. 1951). 
they proved extraordinarily successful instruments of mass education. His own assimilation of the values themselves was so complete that he could convey them without needing to utilize any particular expressions and could spell out their implications in any variety of situations. And, his intimate understanding of India's mind and soul enabled him to interpret, in terms of her own vocabulary and heritage, ideas that were to her novel and foreign. Strange phrases or the names of alien heroes would have made little impact on Indian ears. Wishing to warn a local congress committee that the government would probably use the most extreme measures against a no-tax campaign and that the local congress must, therefore, be very certain that the requisite degree of patience had been instilled in the populace, Gandhi would not mention John Hampden or William Penn for emulation. Instead, he would refer to wellknown parables that lay deep in Hindu memory:

"When the Government military is opened on them, they are expected to expose their willing breasts, not their unwilling backs, to the bullets and still not harbour revenge or resentment. They must let their utensils and belongings be taken away from them, whilst, like Draupadi or Prahlad, they are praying to God and proving their faith in Him."34

In reaching the Indian mind, Gandhi made liberal use of the religious background of her people. Thus, in the very definition of the principal objective of his struggle, Gandhi spoke to India not in the name of democracy, nor of individual liberty nor even of independence. He proclaimed his war to be against Untruth, and for the establishment of Truth. British rule was based on Untruth; the oppressive laws against public meeting, against freedom of speech and of the press, the unconscionable land taxes, the puppet assemblies, the governmental indifference to education, health and welfare of the peoplein short all the things against which the National Congress raised its voicewere bad and intolerable because based on Untruth. But Truth, as every Hindu knew, was nothing else but God, and to reach God is the religious ideal he most cherished. Further, God, that is Truth, could not be reached through sinful means, through the forcible imposition of one's own will or opinion on others. Truth could be reached only through righteous means, through fearless and selfless assertion of truth, through nonviolent resistance to untruth, implying acceptance of the suffering involved in such resistance.

Still, Gandhi and his colleagues did not refuse to employ western ideas directly and through western references. His colleagues ranged from the highly westernized and sophisticated, yet very Indian, Mr. Nehru to the religious, extremely well-informed and immensely tolerant Vinoba Bhave. Their writings cover a vast range. And Gandhi himself talked of political and religious values simultaneously.

But there is a social education-the education outs1de of books-that India has possessed in rich abundance, despite her colossal illiteracy and poverty. As one observer commented a quarter of a century ago:

34. GandHI, Young INDIA 1919-1922, 977 (1923). 
"Through recitations of ancient stories and legends, through shows and passing pageants, through ceremonials and sacraments, through fairs and pilgrimages, the Hindu masses all over India receive a general culture and education which are in no way lower, but possibly higher, than the general level of culture and education received through schools and newspapers, or even through the ministrations of churches in Western Christian lands. It is an education not in the so-called three R's, but in humanity."35

Gandhi fully exploited this base of information, attitudes and outlooks. He constantly sought to link its values to the values underlying western democracy and freedom. He taught through this ancient and familiar code the very essentials of democratic ideals-individual and collective assertion of opinion, respect for the views of the opponent, equality, inviolability of the person and dignity of the individual, courage, patience and, above all, nonviolence and peace.

\section{The Penetration of Gandhi's Message to the Masses}

Gandhi's approach to the political problem of India was not narrowly conceived or coterminous with the achievement of independence from British rule. $\mathrm{He}$, and the National Congress under him, strived for at least a generation to create in India a strong national opinion for democracy and freedom; they religiously eschewed violence and depended exclusively for success on the democratic process of opinion-building. This struggle was accompanied by a vigorous effort at social cleansing, directed against some of the excrescences accumulated around Indian, and particularly Hindu, social life. Gandhi repeatedly insisted that India's freedom depended exclusively on preparedness for freedom: on the creation of the national will and on social self-purification. He stressed that India's salvation was in her own hands, not in those of the British, and that when she attained the requisite strength, the withdrawal of the foreign government would automatically follow.

When violence did occur, Gandhi took the entire responsibility on himself and offered penance by fasting-his way of seeking purification, through suffering. Mysteriously, but nonetheless truly, Gandhi's suffering did purify the whole of India. It compelled every Indian not indifferent to the struggle to think. It pushed democracy a few inches deeper into the new soil. When he fasted, even the remotest peasant knew and prayed for his life and, in many cases, fasted in sympathy with him.

Some measure of the understanding, love and co-operation peasant India accorded Gandhi may be gathered from the quick spread of the hand-spinning program he devised to dramatize the need to be free from foreign industry, as well as to foster co-operation, teach the virtues of manual labor by all castes and classes and bring together in a common endeavor the urbanized and the

35. Muller, What India Can Teach Us, quoted in Sanderland, Inda in Bondage 213 (1932). 
rural Indians. ${ }^{36}$ Even more dramatic was the general acceptance of the discipline Gandhi demanded of a community that wished to engage in a mass civil disobedience campaign. Gandhi would refuse to certify a campaign until the local leadership had satisfied him of the substantial execution of the social program: abolition of untouchability, amicable relations between Hindus and Muslims, and common use of handspun cloth-Swadeshi. In one instance, Bardoli, a district of some 100,000 , was picked by the Congress to offer no-tax and other forms of Civil Disobedience. Gandhi was not finally satisfied with local discipline and national readiness until nearly eight years after the initial preparations. The patient delay of the population was ultimately ended by a successful example of mass Civil Disobedience.

Gandhian reform movements have extended to the countryside. Untouchability, particularly, has been vigorously fought in the small town or "tehsil," which usually has a secondary school and a population ranging between 4,000 and 10,000. Similarly, the Swadeshi has had a sharp impact upon the small towns and villages. And, most strikingly, the movement has worked a spiritual regeneration of Indian youth. Before Gandhi, the haughty English-educated, or semieducated, youth in the small towns and urban centers had become alienated in thought, dress and manners from the rest of India-from rural India in particular. Such young people indulged in vague dreams of future status, usually of a government position. If the dream were realized, the young person was sometimes entirely lost to the rural folk and, despite the strong claims of family ties, entered a world to which his kinsmen could gain no admittance. But if, in the more frequent case, the dream of status came to nothing, the community was left with a frustrated social wreck who could not find in Indian life a place that fitted his aspirations.

The Gandhian movement gave the village and small town youth a new ideal to live by and unleashed a potential energy that had hitherto been dormant. This youth, now liberated from a narrow vision of his own and his country's future, helped spread Gandhi's message. Observance of ideals based on renunciation of foreign cloth, foreign articles and foreign ways made the Gandhian youth extremely popular and important. He was, of course, still a youth, and youths are not normally the most influential members of their communities. But now he was more-he was a crusader, a champion. And in that capacity, he found the fulfillment that had previously escaped him. Using his new-found prestige, he strove to develop programs for the abolition of untouch-

36. The role of handspun cloth is discussed by former Ambassador Bowles: "No item in this program has been more ridiculed by Indian and Western intellectuals, but with the advantage of hindsight, it is easy to see its value. It focused attention on the poverty of the . . people, which was the real problem which free India must face. It forced upper caste Indians to do manual labor.

"It brought Brahmans and untouchables, Hindus and Muslims and Christians together in a common task. It gave Westernized city Indians a chance to cross the gap isolating them from the people. It taught habits of self-discipline. It was also an antidote to too much idle talk. Serving mankind requires drudgery, Gandhi believed." Bowles, AmrbasSADOR's REPORT 64 (1954). 
ability and for adult literacy and to spread the principles of dynamic Nonviolence. Moreover, as a reader of the provincial vernacular newspapersmany of which maintained a fairly high standard of reporting-and of the regular outpourings of Gandhi's press, he came to be a conduit through which ideas and information passed to his less educated contemporaries.

The prime organizers of the Congress at the tehsil level belonged to that class which has in fact always enjoyed moral and social leadership in the countryside. The Gandhian movement simply put zest into these men by giving them tangible and spirited programs; swelled their ranks by intensive propaganda and by attracting the youth; and provided for them a proud mark of identification in the handspun, handwoven clothes which not only Congressmen but all patriots in huge numbers came to accept as their habitual wear.

The tehsil and its leaders thus became important links between the cities and rural India, between the elite and the masses. The voice of the leadership clearly, intelligibly and without interruption reached the tehsil, from which it was further radiated or diffused to the villages. The channels of this diffusion were often not well defined or reliable. Men from the villages surrounding the tehsil town frequently visited it as clients of the tehsil lawyers, as buyers or sellers in the tehsil market and in various other capacities. Devoted organizers were not usually found in the villages, chiefly because even the most rudimentary means of education did not reach the village until after independence. However, the villagers were easily persuaded to spin on the indigenous spinning wheels; they knew that Gandhi stood for homemade goods, for the poor and for right. And whenever they were oppressed by any governmental regulation or official, they knew, too, that they could approach lawyers, shopkeepers and literate men in coarse handspun clothes for anything from writing a petition to waging Satyagraha.

True, illiteracy, poverty and an apathetic if not hostile foreign government prevented anything more than the merest echoes of the new ideas and values from reaching below the tehsil level to the small village. Before the small village could share the experience that had accrued to the tehsil, terrific effort and drive were needed. These were not always forthcoming during Gandhi's lifetime, nor are they apparent in every district of India today. The sharp drop in the level of cultural acquisition and political enlightenment as one moves from a tehsil to a neighboring small village may seem almost to divide India into two distinct segments. Yet the two segments have ever been united by the living bonds of human relationships and everyday contact through the tehsil. The tehsil continues even now to provide the village with leadership through the school teacher, the lawyer, the petty businessman and the social worker. The abolition of landlordism, the drive against illiteracy, the community projects, the new village panchayats, the five-year plans and the elections have put more and more zest into the village, and the gap between the two segments is being closed at a rapid pace. As every day passes, India consolidates her new cultural gains and pushes the roots of enlightenment toward the remotest cottage. 


\section{CoNCLUSION}

The Gandhian movement has had its impact on India over a period that is, for practical purposes, not exceeded by living memory in that land. The movement eschewed not only violence but even hatred or $i 11$ will against the foreign rulers it sought to dislodge. Instead, its leaders put entire faith in the creation in India of a strong feeling for a democratic and free government. They also recognized that a tremendous amount of social cleansing was absolutely necessary for reception of the new values of freedom as an essential part of the national life. To achieve the objectives of creating a social base for a democratic and free society and of building an indomitable national will for freedom, this movement supplemented untiring industry with a subtle use of the available religious background and social education. It presented the new western values to the common man not as foreign and novel doctrines, but as values implied in those he already accepted, and as ideas linked to and projecting from those he held in high esteem. For a generation, it trained Indians to resist governmental invasions of free speech, free assemblage, free association and the various other processes of opinion building. Particularly, it taught them the art of asserting themselves individually and collectively and of insisting on democratic self-expression, while religiously abstaining from the use of force or from harboring ill will, even against an opponent who himself resorted to force and organized violence.

This movement has claimed the lifetime and the energies of some of the best brains in the land. It has drawn into its ranks hundreds of thousands of men and women from all communities. But the movement has without doubt also had its handicaps and limitations. Its greatest handicap was a foreign government that quite understandably viewed its activities with suspicion and hostility and tried to undermine them in every possible way. Another handicap was the orthodox and hidebound character of the social structure of the community in which it had to sprout and grow, a community divided by religion, stratified by caste and extremely suspicious of and impervious to new ideas. Still another handicap was the illiteracy of the masses and their ignorance and indifference to what was happening beyond their little world. All these factors made the task difficult and absorbed much of the vigor of the movement, particularly in the earlier days.

Even before Gandhi's advent, some progress had been made toward overcoming social lethargy by various powerful social reform organizations like the Brahma Samaj and the Arya Samaj, by the National Congress itselfestablished in 1885-and by local patriotic organizations in Maharashtra, Bengal and the Punjab. To some extent, however, these benign influences were offset by terroristic groups that indulged in killing and violence, often with the silent approval of a suppressed and embittered populace. Undoubtedly, the people of India were at times frustrated, impatient and despairing of hope for their own future; no precise direction, no miracle of a sure and unfailing remedy gave them a sense of purposeful mission. Gandhi's dynamic Non-violence provided the direction and the remedy. From the very beginning 
the Gandhian political philosophy had a response from the nation that surprised the leadership itself. Soon, this one movement attracted and absorbed practically all the sporadic social and political organizations that had previously engaged in an ineffective competition for attention. Their formerly diffused energies were channeled into one mighty stream of national effort.

No pretension can be made that even this great movement has given India a full substitute for that gradual unfolding of the democratic idea and the progressive widening of freedom in England over a process of centuries, or for the steady and vigorous operation of free institutions in the United States for nearly the same period. Nonetheless, the Gandhian movement has been the one dominating phenomenon that has characterized the formative decades of modern India. Acquaintance with its progress and achievements is the key to contemporary Indian life. This acquaintance may not altogether quiet concern over the success and viability of democratic and libertarian institutions in India. But by bringing more and important evidence to bear on the issue, it will perhaps greatly qualify a belief that India is not psychologically attuned to the ways of freedom. 


\section{THE YALE LAW JOURNAL}

\begin{tabular}{lll}
\hline VOLUME 67 & JANUARY, 1958 & NUMBer 3 \\
\hline
\end{tabular}

Robert T. Basseches

ALAN J. Hruska

Comment Editors

Rosert L. Bard

Thomas D. BarR

Frederick L. Bernstein

David P. Bicks

Nomaran A. Brkales

Benjamin W. Boley

Richard A. Brady

Newton D. Brenner

Davin Burres

Peter D. Caldwell

Laura M. Chapman

Sydney M. Cone, III

Paul H. DeCoster

Robert J. DeL Tufo

ROBERT J. ENGELAIAN

Mítchel J. Ezer

ARTHUR Fleischer, JR.
STEPHEN N. SHulaian
Editor-in-Chief

Milton P. DeVane

Article and Book Review Editor

Wirliam C. Baskin, JR. Managing Editor

SETH E. FRANK

Thomas N. Fromock

DAVID GoldBerg

Burt W. Griffin

Mrton S. Gwirtzman

REUBEN L. HEDLUNd

ALAN M. HofFMan

JEROLD H. ISRAEL

STEPHEN J. JeLiN

N. Herscher Koblenz

IRVING I. LESNICK

Marcia R. Lockwood

JOHN C. MCGUIRE

JoHN K. MCNULTY

RICHARD MARLIN

Marie McMahon

Business Secretary
Guido Calabresi

W. L. F. FeLstLNer

Note Editors

Richard M. MEYer

Hugh G. Moulton

Michaet J. NassaU

WALTER W. OBERREIT

Richard W. Pendeleton, Jr.

Charles J. Prenttss

BURTON RAFFEI

Richard SeXton

Douglas O. SMith, JR.

LEWIS A. STERN

Colin C. TaIt

JosepH N. TAUBer

STANLEy E. Tobin

Patricia W. Weinberg

T. CECIL WRAY, JR.

Alan L. Wurtzel

\section{CONTRIBUTORS TO THIS ISSUE}

EarL Warken. Chief Justice, Supreme Court of the United States.

Alan F. Westin. Assistant Professor of Government, Cornell University. Member of the District of Columbia Bar.

Pradyuma K. Tripathi. Faculty of Law, University of Delhi. 